Article

\title{
Grain Yields and Nitrogen Use Efficiencies in Different Types of Stay-Green Maize in Response to Nitrogen Fertilizer
}

\author{
Wen Fu, Yang Wang *, Youliang Ye *, Shuai Zhen, Binghui Zhou, Yin Wang, Yujie Hu, Yanan Zhao \\ and Yufang Huang \\ College of Resources and Environment, Henan Agricultural University, Zhengzhou 450002, China; \\ fuwenchina@163.com (W.F.); zhen123nongda@gmail.com (S.Z.); zhoubinghui88888@gmail.com (B.Z.); \\ wangyin981022@gmail.com (Y.W.); hu080369@gmail.com (Y.H.); zhaoyanan@henau.edu.cn (Y.Z.); \\ huangyufang@henau.edu.cn (Y.H.) \\ * Correspondence: wangyang1106@henau.edu.cn (Y.W.); ylye@henau.edu.cn (Y.Y.)
}

Received: 7 March 2020; Accepted: 1 April 2020; Published: 9 April 2020

\begin{abstract}
The stay-green leaf phenotype is typically associated with increased yields and improved stress resistance in maize breeding, due to higher nitrogen $(\mathrm{N})$ nutrient levels that prolong greenness. The application of $\mathrm{N}$ fertilizer can regulate the $\mathrm{N}$ status of plants, and furthermore, impact the photosynthetic rates of leaves at the productive stage; however, $\mathrm{N}$ deficiencies and $\mathrm{N}$ excesses will reduce maize yields. Consequently, it is necessary to develop $\mathrm{N}$ fertilizer management strategies for different types of stay-green maize. For this study, the senescent cultivar Lianchuang 808 (LC808), moderate-stay-green cultivar Zhengdan 958 (ZD958), and over stay-green cultivar Denghai 685 (DH685) were selected as experimental models. Our results revealed that yields of ZD958 were slightly higher than DH685 and notably improved over than LC808. Compared with a non-stay-green cultivar LC808, ZD958 and DH685 still maintained higher chlorophyll contents and cell activities following the silking stage, while efficiently slowing the senescence rate. The supply of $\mathrm{N}$ fertilizer significantly prolonged leaf greenness and delayed senescence for ZD958 and DH685; however, the effect was not obvious for LC808. The stem remobilization efficiency of $\mathrm{N}$ was higher in the moderate-stay-green cultivar ZD958, in contrast to LC808, while the transfer of leaf N was lower than LC808, which guaranteed high leaf $\mathrm{N}$ levels, and that sufficient $\mathrm{N}$ was transferred to grains in ZD958. To obtain the highest yields, the optimal $\mathrm{N}$ fertilizer rates were $228.1 \mathrm{~kg} \mathrm{hm}^{-2}$ for LC0808, $180 \mathrm{~kg} \mathrm{hm}^{-2}$ for ZD958, and $203.8 \mathrm{~kg} \mathrm{hm}^{-2}$ for DH685. In future, the selection of stay-green type crops might serve as an important agricultural strategy to reduce the quantity of $\mathrm{N}$ fertilizer and increase $\mathrm{N}$ efficiency.
\end{abstract}

Keywords: maize; senescence; nitrogen stress; stay-green; physiological characteristics

\section{Introduction}

Maize (Zea mays L.) is one of the world's most widely cultivated crops, providing food and animal feed as well as being a source of biofuel. [1,2]. Maize is predicted to become the first-ranked crop globally by 2020 [3]. The countries with the largest planted areas of maize are the USA, China and Brazil [4]. In the past century, maize grain yield has increased eight-fold with the majority of the yield being attributed to selection and hybrid breeding [5], which was due to increased maize greenness [6,7].

In 1987, Willman (1987) initially classified maize as non-stay-green and stay-green, contingent on the degree of the greenness of its leaves. The former category is also referred to as a premature senescence cultivar, which means that its leaves become less green 30 days after flowering, and then basically disappear at the grain maturity stage. The latter category refers to a sustained level of green (the overall proportion of a leaf that stays green) and no obvious loss of color at the maturity stage [8]. 
Early senescence translates to reduced green leaf area and photosynthesis, and significantly decreased grain yields [9]. While the chlorophyll and soluble protein content of stay-green maize leaves decrease slowly during senescence, the functionality of leaves is extended significantly $[10,11]$ However, yields cannot be further increased, and are even reduced, when the leaf greenness score exceeds a certain threshold (over-stay-green), as much more $\mathrm{N}$ is retained in the leaves for photosynthesis, which does not transfer to grains, thus, reduce grain $\mathrm{N}$ concentration [12-14].

Further to $\mathrm{N}$ being the most essential nutrient for plant growth and development, it is also one of the nutritional elements with the greatest impact on grain yields $[15,16]$. Efficient $\mathrm{N}$ fertilizer management is vital to increase crop yields, improve soil fertility and minimize environmental risk [17]. As a critical component of chlorophyll, plant $\mathrm{N}$ levels are intimately related to leaf senescence and photosynthesis [18]. During the reproductive growth stage, $\mathrm{N}$ supplies prolong leaf greenness, while shortages of $\mathrm{N}$ induce early leaf senescence [19].

Leaf nitrogen $(\mathrm{N})$ and photosynthesis are connected as most of the $\mathrm{N}$ in leaves is associated with photosynthetic machinery $[20,21]$. In contrast to a non-stay-green cultivar, the stay-green cultivar maintained more reduced nitrogen, chlorophyll content and higher nitrate reductase and carboxylase enzyme activities, which contributed to the accumulation of additional photosynthetic products during the grain-filling period [22]. In particular, the yield-increasing potential of the stay-green grain was more evident under the condition of $\mathrm{N}$-deficiency stress [23].

To prolong leaf greenness following anthesis for the stay-green maize phenotype, more $\mathrm{N}$ was retained in the leaves, which influenced the accumulation of $\mathrm{N}$ in corn kernels. For senescent maize, the transfer of leaf $\mathrm{N}$ to reproductive organs is accompanied by rapid leaf senescence, which affects leaf $\mathrm{CO}_{2}$ fixation [14]. It follows that non-stay-green or stay-green cultivars have inherent advantages and disadvantages, where the application of $\mathrm{N}$ fertilizer might effectively regulate the $\mathrm{N}$ status of plants and further impact the process of leaf senescence. Therefore, we hypothesized that various stay-green types of maize should obtain optimized $\mathrm{N}$ fertilizer application rates to maintain leaf photosynthesis and $\mathrm{N}$ remobilization efficiencies. The objectives of this present study were to: (1) compare the senescence characteristics affected by different $\mathrm{N}$ application rates in various stay-green types of maize; and (2) determine the optimal $\mathrm{N}$ fertilizer rates for different stay-green types of maize.

\section{Materials and Methods}

\subsection{Plant Material and Experimental Design}

This study was conducted in Yuzhou City, Henan Province ( $\left.34^{\circ} 27^{\prime} \mathrm{N}, 113^{\circ} 34^{\prime} \mathrm{E}\right)$, where the soil type of the test site was fluvo-aquic and clay. The $\mathrm{pH}$ of the cultivated soil layer was 7.44 with an organic matter content of $20.69 \mathrm{~g} \cdot \mathrm{kg}^{-1}$, which contained $0.96 \mathrm{~g} \cdot \mathrm{kg}^{-1}$ total nitrogen, $19.85 \mathrm{mg} \cdot \mathrm{kg}^{-1}$ available phosphorus, $88.67 \mathrm{mg} \cdot \mathrm{kg}^{-1}$ available potassium, and $58 \mathrm{~kg} \mathrm{hm}^{-2}$ inorganic nitrogen $\left(\mathrm{N}_{\min }\right)$.

Cultivar experiment: In 2017, the present study was laid out in a randomized complete block design with three replications. A total of 20 maize cultivars (which are widely cultivated on the Huang-Huai-Hai plain) were used for the experiment, with the specific types of maize listed in Table 1. Seeds were mechanically sown on the 10th of June at a hill spacing of $0.60 \mathrm{~m} \times 0.27 \mathrm{~m}$, with 61,725 plants ha ${ }^{-1}$, with plot dimensions of $4 \mathrm{~m} \times 10 \mathrm{~m}$. Nitrogen $\left(180 \mathrm{~kg} \mathrm{~N} \mathrm{hm}^{-2}\right)$ in the form of urea was applied in two splits with $50 \%$ at basal and $50 \%$ at the 10-leaf stage (45 d after sowing). Phosphorus $\left[90 \mathrm{~kg}\left(\mathrm{P}_{2} \mathrm{O}_{5}\right) \mathrm{hm}^{-2}\right]$ in the form of calcium superphosphate, and potassium $\left[90 \mathrm{~kg}(\mathrm{KCl}) \mathrm{hm}^{-2}\right]$ were applied as a basal dose. The leaf SPAD value was measured at the silking and maturity stages, and the grain yield was weighed at harvest. 
Table 1. The 20 selected maize cultivars.

\begin{tabular}{cccc}
\hline No. & Cultivar & No. & Cultivar \\
\hline 1 & Zhengdan958 & 11 & Denghai939 \\
2 & Xianyu048 & 12 & Fengdecunyu10 \\
3 & Lianchuang808 & 13 & Lianchuang839 \\
4 & Cunyu10 & 14 & Lianchuang825 \\
5 & Dika653 & 15 & Denghai605 \\
6 & DikaJ1652 & 16 & Denghai533 \\
7 & D4111 & 17 & Denghai685 \\
8 & Dedan5 & 18 & Xianyu1466 \\
9 & Denghai618 & 19 & Xianyu1366 \\
10 & D4117 & 20 & Xianyu335 \\
\hline
\end{tabular}

$N$ rate experiment: In 2018 and 2019, the study samples were selected for cultivar experiments, including a senescent cultivar Lianchuang 808 (LC808), moderate-stay-green cultivar Zhengdan 958 (ZD958) and over-stay-green cultivar Denghai 685 (DH685), with the performance of the different maize cultivars in the field at maturity shown in Figure 1. Seeds were mechanically sown on June 08, at a hill spacing of $0.60 \mathrm{~m} \times 0.27 \mathrm{~m}$, with 61,725 plants $\mathrm{hm}^{-2}$, with the dimensions of each plot being $4 \mathrm{~m} \times 10 \mathrm{~m}$. The experimental design was a split plot with three replicates. three maize cultivars were applied to main plots, and five $\mathrm{N}$ treatment rates $\left(0,120,180,240\right.$ and $\left.360 \mathrm{~kg} \mathrm{~N} \mathrm{hm}^{-2}\right)$ as the subplots.

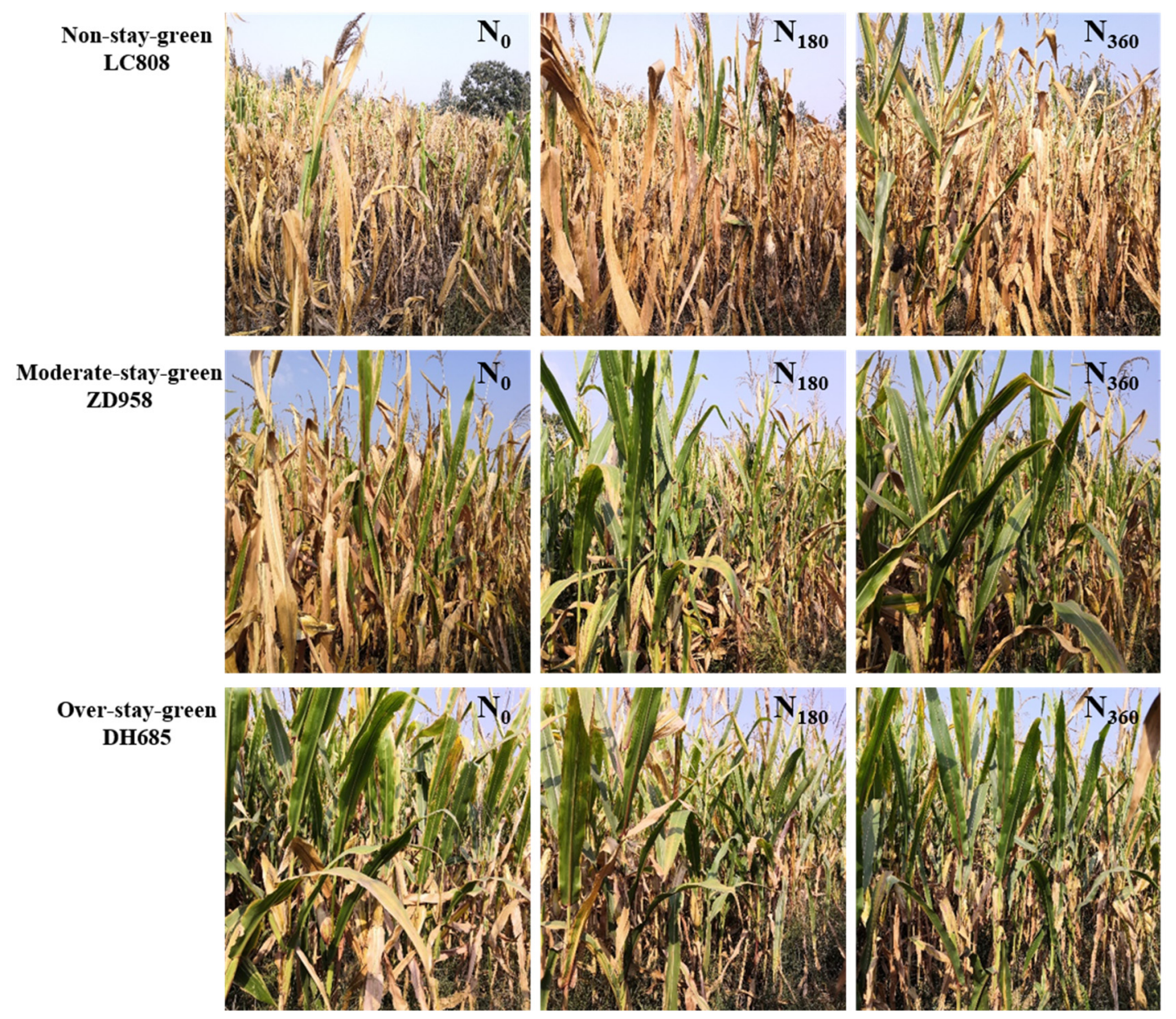

Figure 1. The performance of different stay-green types of maize under the different field nitrogen $(\mathrm{N})$ levels at the maturation stage. 
Urea served as the source of $\mathrm{N}$, which was applied in two splits, with $50 \%$ at basal and $50 \%$ at the 10-leaf stage (45 d after sowing). Phosphorus $\left[90 \mathrm{~kg}\left(\mathrm{P}_{2} \mathrm{O}_{5}\right) \mathrm{hm}^{-2}\right]$ in the form of calcium superphosphate, and potassium $\left[90 \mathrm{~kg}(\mathrm{KCl}) \mathrm{hm}^{-2}\right]$ were applied as a basal dose. The basal fertilizer was applied to the ground following manual broadcasting, whereas $\mathrm{N}$ topdressing was applied by means of side-dressing. Nicosulfuron and atrazine were applied at the three-leaf stage for weed control, whereas thiophanate-methyl and lambda-cyhalothrin were applied at the eight-leaf stage to prevent diseases and insect attack.

\subsection{SPAD Values Measurements}

The SPAD readings were obtained using a hand-held dual-wavelength meter (SPAD-502, chlorophyll meter, Minolta Camera Co., Ltd., Japan) from the mid-point of the ear leaf at the maize V6 stage ( $25 \mathrm{~d}$ after sowing), V12 stage ( $43 \mathrm{~d}$ after sowing), R1 stage ( $62 \mathrm{~d}$ after sowing), R3 stage ( $80 \mathrm{~d}$ after sowing) and R6 stage (107 d after sowing). The ear leaves of ten consecutive plants in one of the central rows were labeled with small plastic tags, and the SPAD values were measured in the morning (8:00-11:00 am). Finally, their average values are recorded as the values of the leaves.

\subsection{Relative Leaf Conductivity}

The ear leaves of 3 representative plants in each plot were selected as physiological test materials in the morning (10:00-12:00 am) at the silking stage and mature stage respectively, and the size and position of leaves in each ear position were consistent in the selection. To determine the relative leaf conductivity, $40 \mathrm{~mL}$ of distilled water was added to the leaves in a clean beaker, where after the conductivity $R_{0}$ was measured using a conductivity meter (DDSJ 308, Shanghai). Five to eight well-grown leaves were removed from the top of the plant, which were then wiped with distilled water and dried, while avoiding the main veins. A hole punch Ø5 $\mathrm{mm}$ was used to obtain the mesophyll tissue (10 pieces each $\times 3$ ). These samples were placed in a beaker, which was then sealed with plastic wrap and soaked for 5-6 h, after which the conductivity $R_{1}$ was measured. Subsequently, the samples were placed in a water bath, boiled for $30 \mathrm{~min}$, and then removed. After cooling to room temperature, the conductivity $R_{2}$ was measured again. The relative conductivity $R$ was calculated as: $\mathrm{R}=\left(\mathrm{R}_{1}-\mathrm{R}_{0}\right) /\left(\mathrm{R}_{2}-\mathrm{R}_{0}\right)$.

\subsection{Chlorophyll Content}

The ear leaves of 3 representative plants in each plot were selected as physiological test materials in the morning (10:00-12:00 am) at the silking stage and mature stage respectively, and the size and position of leaves in each ear position were consistent in the selection. The leaf disc samples were homogenized in $5 \mathrm{~mL}$ of an $80 \%$ acetone solution added to $0.01 \mathrm{~g} \mathrm{CaCO}_{3}$, and then centrifuged at $2000 \times g$ for $10 \mathrm{~min}$ at $10^{\circ} \mathrm{C}$. The supernatant was collected, where the final volume of the extract was $25 \mathrm{~mL}$ using $80 \%$ acetone. The absorbance (A) of the extracts was determined at $470,646.8$ and $663.2 \mathrm{~nm}$ using a spectrophotometer, and an estimate of the chlorophyll content $a$ [Chl $\left.a=12.2 .79 \times \mathrm{A}_{646.8}\right]$, chlorophyll $b\left[\mathrm{Chl} b=21.50 \times \mathrm{A}_{646.8}-5.10 \times \mathrm{A}_{663.2}\right]$, chlorophyll $(a+b)\left[\mathrm{Chl}(a+b)=7.15 \times \mathrm{A}_{663.2}+\right.$ $18.71 \times \mathrm{A}_{646.8}$ ] was obtained according to Lichthenthaler (1987) [24].

\subsection{Plant Sampling and Determination of Total N Concentration}

At maturity (107 d after sowing), five plants from each plot were sampled, and then dissected into leaves, stems, cobs and grains. These fresh materials were oven dried at $105^{\circ} \mathrm{C}$ for $30 \mathrm{~min}$ and then at $75{ }^{\circ} \mathrm{C}$, until a constant mass was achieved. The seeds harvested in each plot after sun-drying and threshing were weighed, The grain moisture of corn grains was adjusted to a $13 \%$, which was recorded as the yield of the plot. and the samples in each plot were measured repeatedly for 3 times. The plant materials were ground to facilitate passage through a l-mm mesh screen, and then digested by $\mathrm{H}_{2} \mathrm{SO}_{4}$ and $\mathrm{H}_{2} \mathrm{O}_{2}$. The total $\mathrm{N}$ concentration of the digested samples was determined using an automated continuous flow analyzer (Seal, Norderstedt, Germany). 


\subsection{Statistical Analyses}

The formula for calculating the absorption and utilization efficiency parameters of the nitrogen fertilizer:

TNA $\left[\mathrm{kg} \mathrm{hm}^{-2}\right]=$ plant $\mathrm{N}$ concentration $\left[\mathrm{kg} \mathrm{kg}^{-1}\right] \times$ plant dry matter $\left[\mathrm{kg} \mathrm{hm}^{-2}\right]$;

NRE [\%] = (TNA of N applied - TNA of N omission) $\left[\mathrm{kg} \mathrm{hm}^{-2}\right] / \mathrm{N}$ applied $\left[\mathrm{kg} \mathrm{hm}^{-2}\right] \times 100[\%]$;

$\mathrm{N}-\mathrm{PFP}\left[\mathrm{kg} \mathrm{kg}^{-1}\right]=$ Grain yield $\left[\mathrm{kg} \mathrm{hm}^{-2}\right] / \mathrm{N}$ applied $\left[\mathrm{kg} \mathrm{hm}^{-2}\right]$;

NHI [\%] = grain N accumulation $\left[\mathrm{kg} \mathrm{hm}^{-2}\right] /$ TNA $\left[\mathrm{kg} \mathrm{hm}^{-2}\right] \times 100[\%]$

where TNA is the total $\mathrm{N}$ accumulation, NRE is the $\mathrm{N}$ recovery efficiency, N-PFP is the $\mathrm{N}$ partial factor productivity, $\mathrm{NHI}$ is the $\mathrm{N}$ harvest index.

A one-way analysis of variance (ANOVA) was applied to assess differences for each parameter using the Statistical Software Package for Social Science (SPSS, version 20.0). The mean values of the treatments were compared on the basis of the least significant difference test (LSD). The graphs were plotted using the Origin 9.0 software program. Linear regression was used to represent the relationships between yield and SPAD difference of the 20 maize cultivars. In the linear-plateau model, the point at which an increase in the independent variable no longer results in an increase in the dependent variable is termed the critical point or the critical rate. The inclined segment is described by the equation $y=a x+b$ (if $x$ critical point), and the horizontal segment is described by the equation $y=c$ (if $x>$ critical point), where $a$ is the slope of the inclined segment and $b$ and $c$ are intercepts. SAS software (SAS 8.0, USA) was used to conduct the analyses and to obtain the relevant parameters.

\section{Results}

\subsection{Relationship between $\triangle S P A D$ and Grain Yield}

Fitting the difference between the SPAD of maize leaves at the silking and maturity stages $(\triangle \mathrm{SPAD})$ to the yield, revealed a relationship simulated by a quadratic functional relationship between the $\triangle$ SPAD and grain yield $\left(y=2.278 x^{2}+114.17 x+7809.4, R^{2}=0.496\right.$; Figure 2$)$. With higher $\triangle$ SPAD, the grain yield initially increased and then decreased. The yield attained its peak when $\triangle$ SPAD was 25 , after which the yield began to decrease. This suggested that the proper stay-green increased the grain yields of maize; however, the over-stay-green reduced yields.

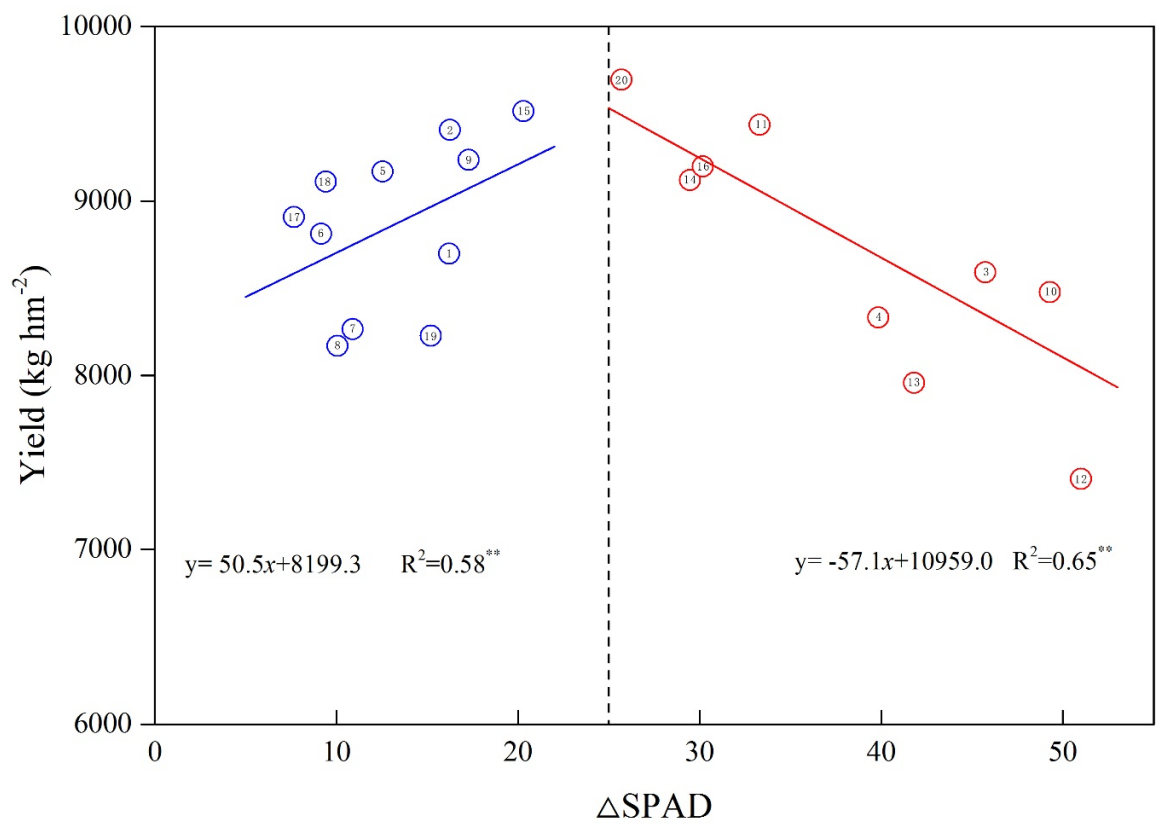

Figure 2. Relationships between the yield and SPAD difference of the 20 maize cultivars. The number in the circle represents the order of cultivar, and the name of cultivar refer to Table 1. 


\subsection{SPAD Value}

With the growth of crops, the SPAD value of the different types of stay-green maize leaves was initially increased and then decreased, obtaining the maximum peak at the R1 stage (Figure 3). From the R1 to R6 stage (2018) the SPAD value of the leaves decreased significantly, with LC808 having the largest average decline $(82.1 \%)$ followed by ZD958 (39.6\%), where the lowest was DH685 (22.7\%). Consistent with the SPAD reduction trend in 2018, the LC808, ZD958 and DH605 decreased by $84.8 \%, 43.5 \%$ and $22.8 \%$, respectively, in 2019. Except for DH685 cultivar in 2018, there was no significant difference among treatments at jointing stage, but significant differences began to appear among treatments at the silking stage. With the increase of nitrogen application rate, SPAD increased, but when it exceeded $180 \mathrm{~kg} \mathrm{~N} \mathrm{hm}^{-2}$, the increase of SPAD was not significant. At maturity, LC808 had no significant difference among treatments, and the treatment of $180-360 \mathrm{~kg} \mathrm{~N} \mathrm{hm}^{-2}$ of other cultivars was significantly higher than that of no-N treatments.

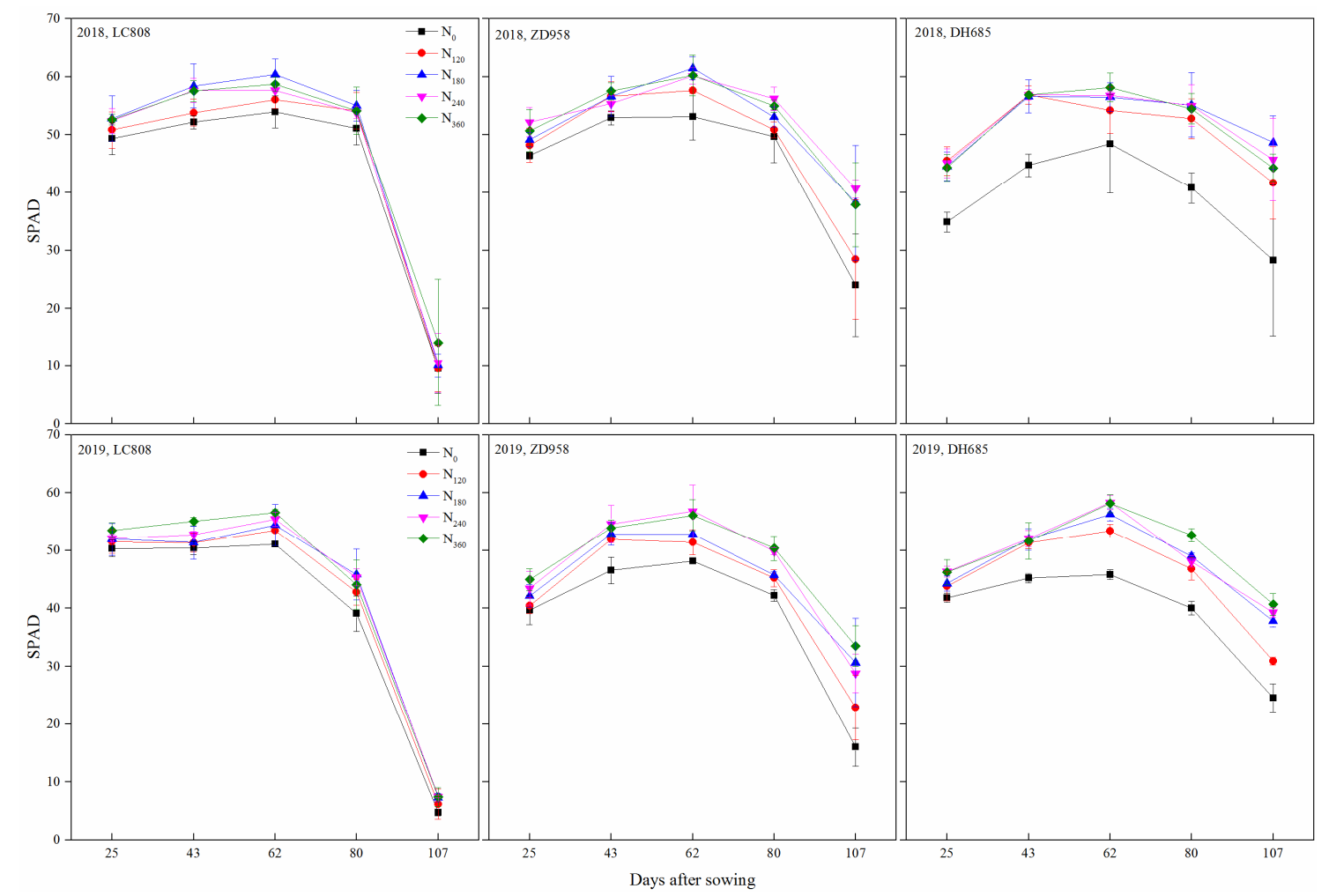

Figure 3. Dynamic of SPAD in different stay-green types of maize under the different $\mathrm{N}$ levels. Error bars indicate the SD.

In contrast to no- $\mathrm{N}$ treatments, the application of $\mathrm{N}$ fertilizer obviously increased the leaf SPAD value, where typically, DH685 exhibited the largest increase between the three cultivars. At the R6 stage, there was no significant difference in SPAD values between the different $\mathrm{N}$ levels of LC808, which were all $<20$. The ZD958 and DH685 were still significantly affected by N fertilizer; however, no obvious differences between the $\mathrm{N}_{180}, \mathrm{~N}_{240}$, and $\mathrm{N}_{360}$ treatments were observed. 


\subsection{Chlorophyll Content}

At the R1 stage, the application of $\mathrm{N}$ fertilizer significantly increased the total chlorophyll content in contrast to no-N treatments; however, no significant differences were observed between the different $\mathrm{N}$ addition treatments (except LC808 in 2018) (Figure 4). At the R6 stage, the total chlorophyll was increased with higher $\mathrm{N}$ application levels, and there were no significant differences observed at 180-360 $\mathrm{kg} \mathrm{N} \mathrm{hm}^{-2}$ loadings. Compared with the R1 stage, the chlorophyll content was significantly decreased at the R6 stage, where the reduction of $\mathrm{Chl} a$ content was the main driver behind the decline in total chlorophyll content.

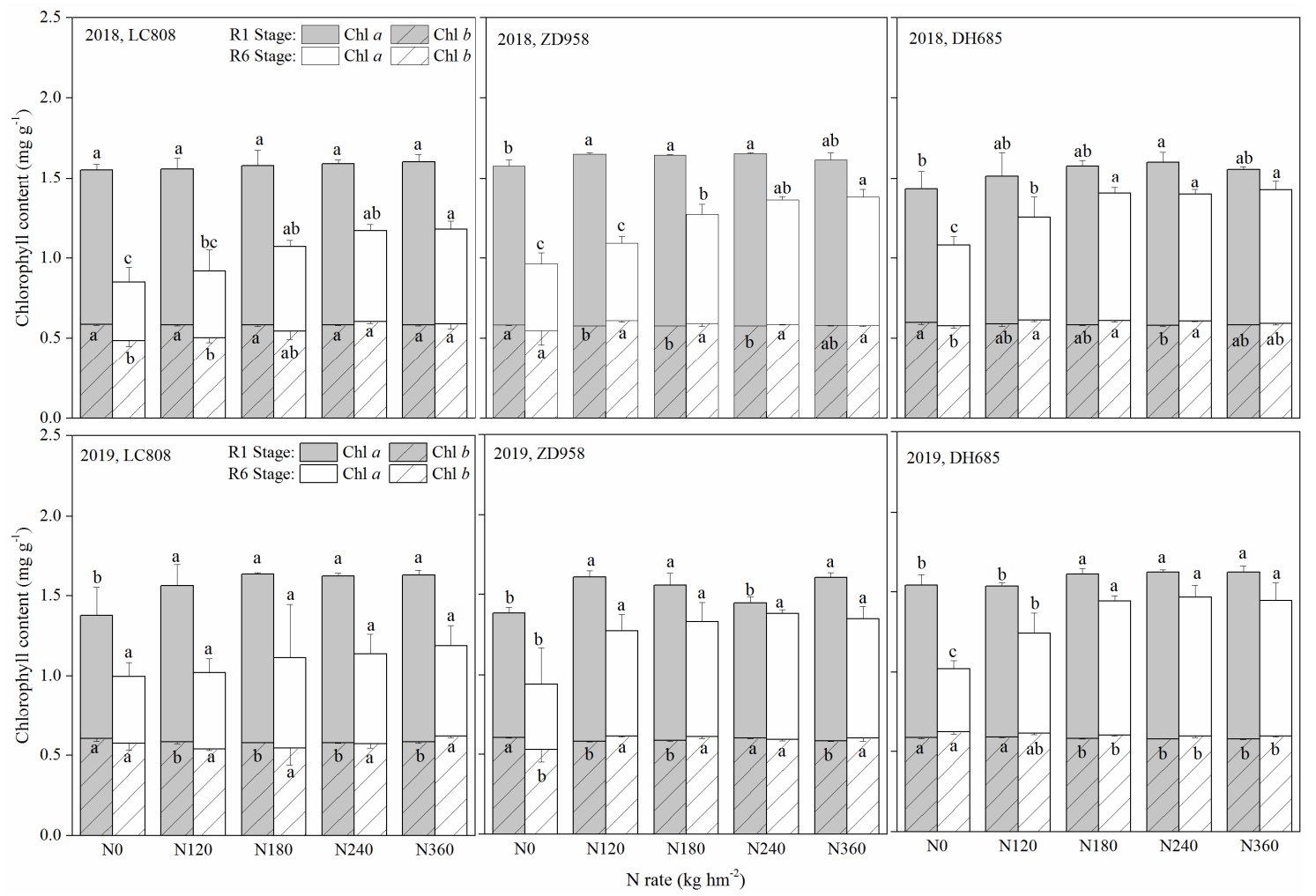

Figure 4. Chlorophyll content of different stay-green types of maize under the different $\mathrm{N}$ levels. Additional letters represent significant differences $(p<0.05)$ in $\mathrm{Chl} a$ or $\mathrm{Chl} b$ at the same growth stage between the different $\mathrm{N}$ rates. Error bars indicate the SD.

The differences in total chlorophyll content between the R1 and R6 stages were decreased with higher $\mathrm{N}$ applications. Moreover, the differences in chlorophyll content between the R1 and R6 stages were inconsistent for all cultivars. In contrast to the R1 stage, the mean total chlorophyll contents of LC808, ZD958, DH685 in 2018, were reduced by $9.1 \%, 25.5 \%$ and $14.6 \%$ respectively, and by $36.0 \%$, $17.5 \%$ and $16.5 \%$, respectively, in 2019 .

\subsection{Relative Electrical Conductivity (EC)}

For the three maize cultivars, the relative EC of R1 stage was significantly less than that of the R6 stage, whereas the relative EC was reduced with the higher addition of $\mathrm{N}$ at the same growth stage (Figure 5). At the R1 stage, the average relative EC over all $\mathrm{N}$ treatments for the three cultivars was LC808 < ZD958 < DH685 (2018-19). However, the average relative EC value of the cultivars at the R6 stage showed the opposite trend in contrast to the R1 stage. At the R6 stage, the application of $\mathrm{N}$ fertilizer significantly reduced the relative EC values. The differences in relative EC between $\mathrm{N}_{0}$ and $\mathrm{N}_{360}$ treatments were 0.03 (LC808), 0.15 (ZD958) and 0.26 (DH685) in 2018, and 0.06 (LC808), 
0.15 (ZD958) and 0.20 (DH685) in 2019. This indicated that the application of $\mathrm{N}$ fertilizer had the highest effects on the relative EC of DH685, with ZD958 second, and the poorest for LC808.

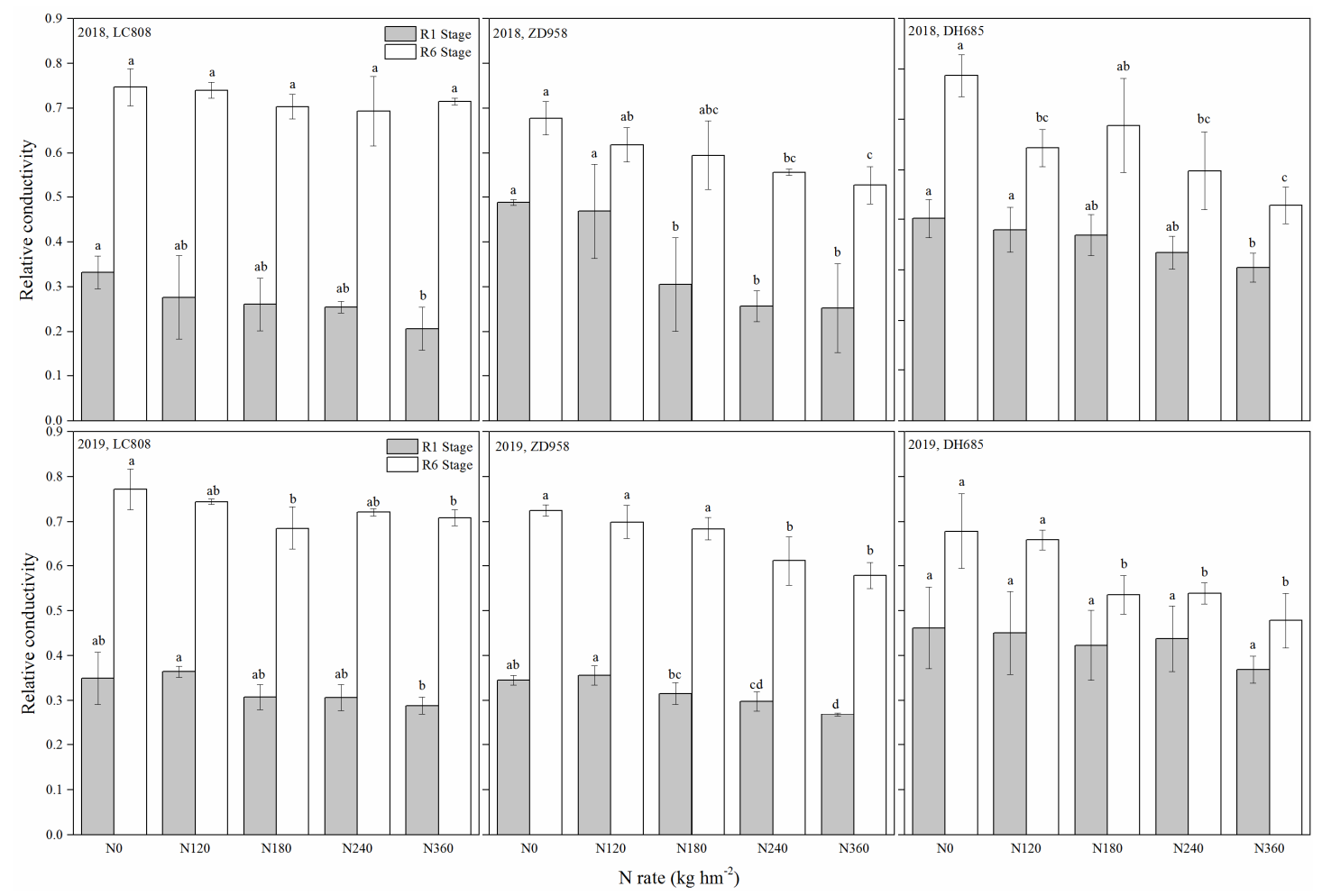

Figure 5. Relative conductivity of the different stay-green types of maize under different $\mathrm{N}$ levels. Additional letters represent significant differences $(p<0.05)$ at the same growth stage between the different $\mathrm{N}$ rates. Error bars indicate the SD.

\subsection{Grain Yield}

The average maize yield in 2019 was $22.2 \%$ higher than that of 2018, which amounted to a significant difference in yields between these two years (Figure 6). The grain yield was increased with higher $\mathrm{N}$ rates, which attained a maximum when the quantity of $\mathrm{N}$ fertilizer was in the range of from $180-240 \mathrm{~kg} \mathrm{~N} \mathrm{hm}^{-2}$. The $\mathrm{N}_{360}$ treatment yields were significantly decreased in contrast to $\mathrm{N}_{240}$ treatments in 2018 (except for cultivar LC808), whereas no significant decrease was observed in 2019. The yield of cultivar LC808 was less than that of ZD958 and DH685 for the two years. A regression equation revealed that the highest yields for LC808, ZD958 and DH685 were 7730.5, 8949.2 and $8775.6 \mathrm{~kg} \mathrm{hm}^{-2}$, with corresponding $\mathrm{N}$ fertilizer rates at $228.1,180.0$ and $203.8 \mathrm{~kg} \mathrm{hm}^{-2}$. Consequently, the moderate enhancement of the capacity of stay-green both increased grain yields and decreased the required $\mathrm{N}$ fertilizer dosage. 


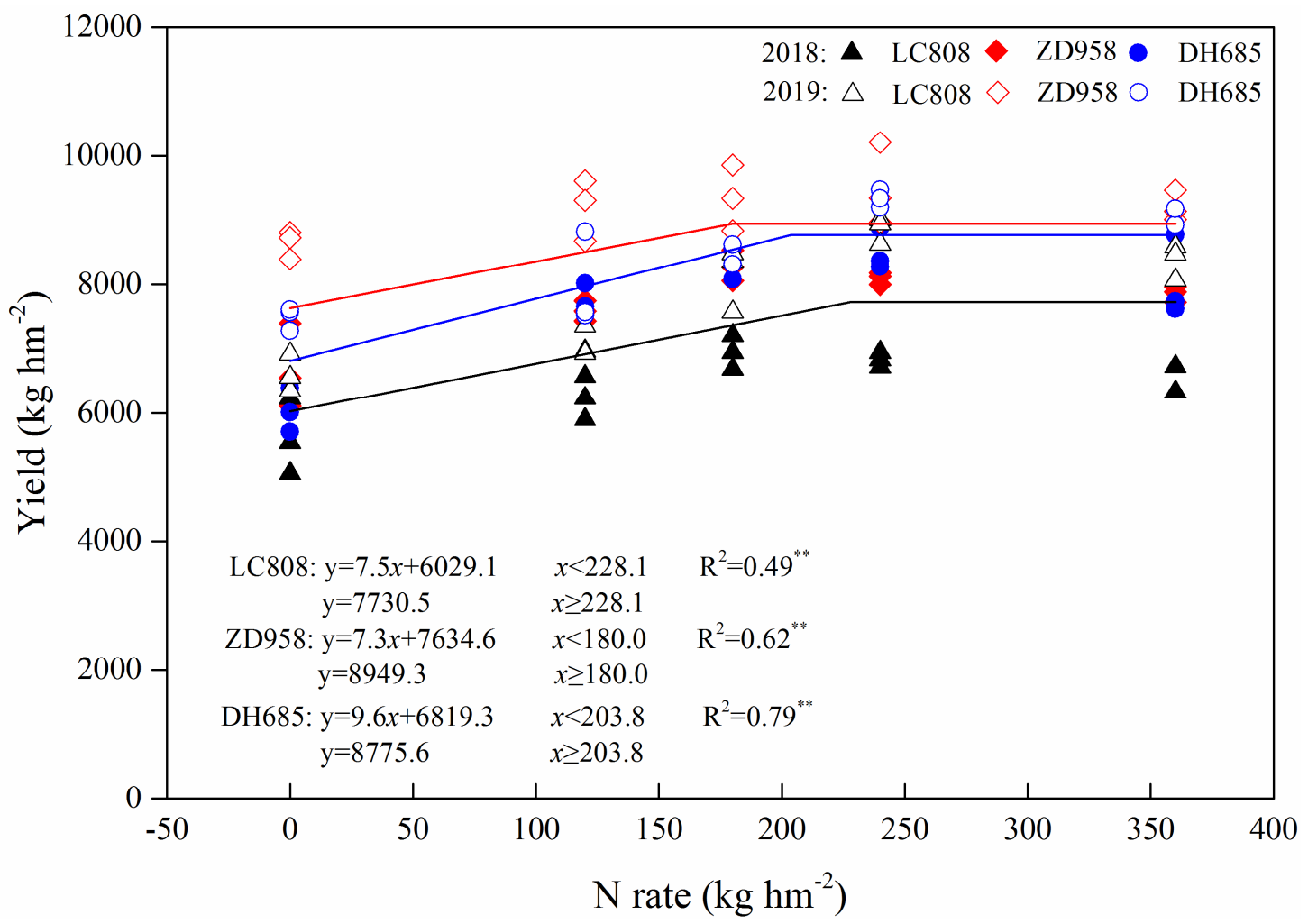

Figure 6. Regression equation between $\mathrm{N}$ fertilizer rates and yields for different types of staygreen maize.

\section{6. $N$ Accumulation and $N$ Use Efficiency}

The accumulation of $\mathrm{N}$ in straw (stem and leaf) at the R1 stage was obviously higher than at the $\mathrm{R} 6$ stage, and stem $\mathrm{N}$ accumulation was significantly higher than the accumulation leaf $\mathrm{N}$ over the two years (Figure 7). The mean stem $\mathrm{N}$ transfer ratios across the different $\mathrm{N}$ treatments for the two years were $54.8 \%$ (LC808), 58.9\% (ZD958) and 50.3\%(DH685), while the mean leaf $\mathrm{N}$ transfer ratios were $63.5 \%$ (LC808), 47.8\% (ZD958) and 41.0\% (DH685). For the same cultivars, the stem $\mathrm{N}$ transfer ratio was decreased with higher $\mathrm{N}$ rates across all cultivars, and the leaf $\mathrm{N}$ transfer ratio was increased with higher $\mathrm{N}$ rates for LC808, while it was decreased with higher N rates for ZD958 and DH685.

The $\mathrm{N}$ recovery efficiency (NRE), $\mathrm{N}$ partial factor productivity (N-PFP) and $\mathrm{N}$ harvest index (NHI) were decreased under higher $\mathrm{N}$ application rates, and the effect of $\mathrm{N}$ on NHI was significantly lower than that of NRE and N-PFP (Table 2). These three related $\mathrm{N}$ use efficiency parameters were significantly different over the two years; the mean NRE and N-PFP in 2018 were less than that in 2019, whereas NHI showed the opposite trend. Furthermore, there were significant differences in N-PFP and NHI between cultivars, the N-PFP of the ZD958 and DH685 cultivars was higher than that of LC808, while the NHI of ZD958 was highest, followed by LC808, with DH685 being lowest. 


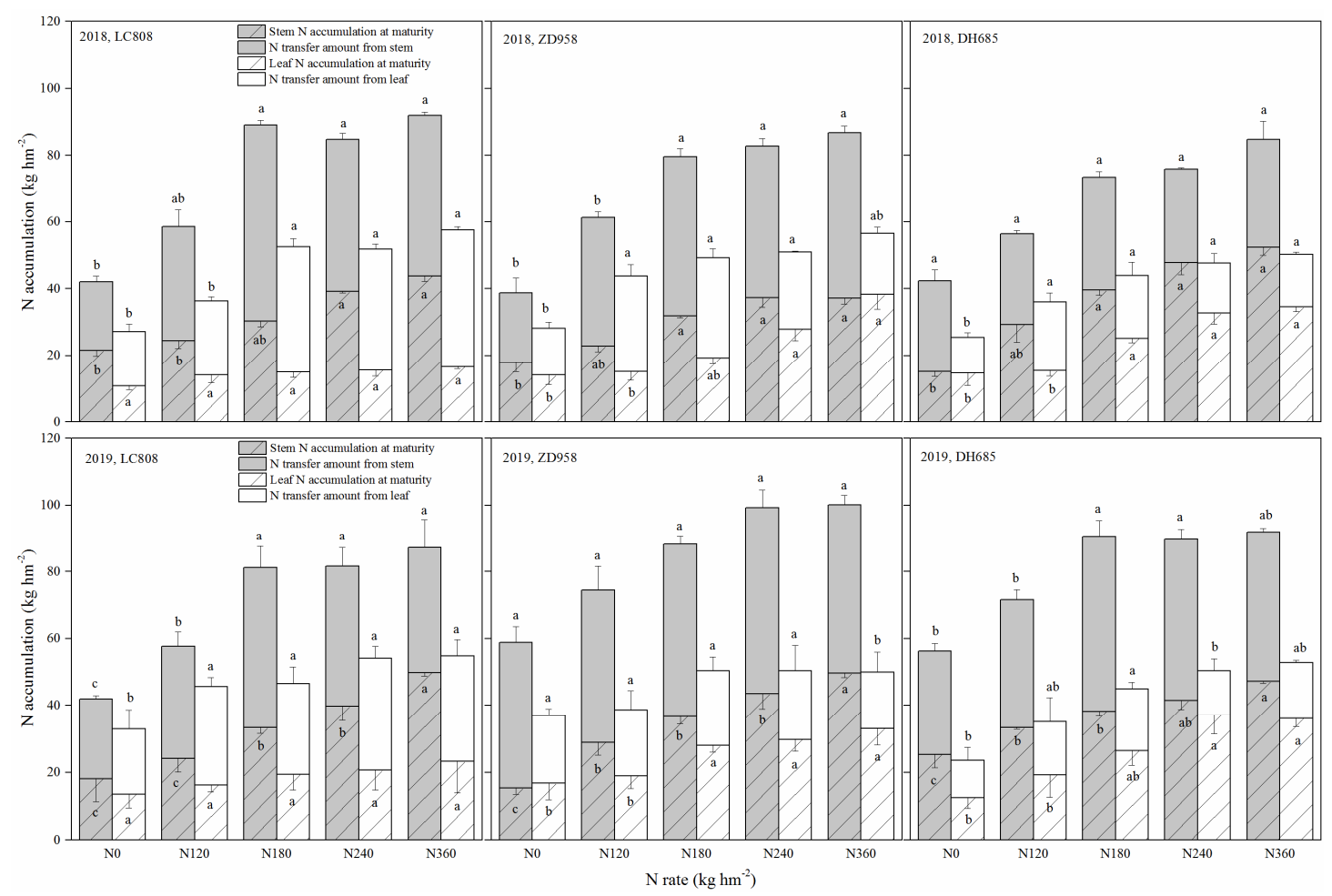

Figure 7. Effects of different $\mathrm{N}$ fertilizer application rates on $\mathrm{N}$ use efficiencies of different types of stay-green maize. Additional letters represent significant differences $(p<0.05)$ in $\mathrm{N}$ accumulation or $\mathrm{N}$ transfer amount for the same organ between the different $\mathrm{N}$ rates. Error bars indicate the SD.

Table 2. Effects of different $\mathrm{N}$ fertilizer application rates on the $\mathrm{N}$ use efficiencies of different types of stay-green maize.

\begin{tabular}{|c|c|c|c|c|}
\hline Cultivar & N Level & N Recovery Efficiency (\%) & N PFP (kg kg-1) & N Harvest Index (\%) \\
\hline \multicolumn{5}{|l|}{2018} \\
\hline \multirow[t]{5}{*}{ LC808 } & $\mathrm{N}_{0}$ & - & - & $65.2 \mathrm{a}$ \\
\hline & $\mathrm{N}_{120}$ & $33.5 \mathrm{a}$ & $57.0 \mathrm{a}$ & $60.3 a$ \\
\hline & $\mathrm{N}_{180}$ & $34.0 \mathrm{a}$ & $38.6 b$ & $65.7 \mathrm{a}$ \\
\hline & $\mathrm{N}_{240}$ & $37.1 \mathrm{a}$ & $26.0 \mathrm{c}$ & $62.6 a$ \\
\hline & $\mathrm{N}_{360}$ & $22.3 b$ & $16.8 \mathrm{~d}$ & $62.1 \mathrm{a}$ \\
\hline \multirow[t]{5}{*}{ ZD958 } & $\mathrm{N}_{0}$ & - & - & $73.2 \mathrm{a}$ \\
\hline & $\mathrm{N}_{120}$ & $38.6 a$ & $63.2 \mathrm{a}$ & $76.4 \mathrm{a}$ \\
\hline & $\mathrm{N}_{180}$ & $35.0 \mathrm{a}$ & $44.8 \mathrm{~b}$ & $72.1 \mathrm{a}$ \\
\hline & $\mathrm{N}_{240}$ & $34.7 \mathrm{a}$ & $33.8 \mathrm{c}$ & $70.0 \mathrm{a}$ \\
\hline & $\mathrm{N}_{360}$ & $28.3 a$ & $21.5 \mathrm{~d}$ & $63.1 b$ \\
\hline \multirow[t]{5}{*}{ DH685 } & $\mathrm{N}_{0}$ & - & - & $58.5 b$ \\
\hline & $\mathrm{N}_{120}$ & $47.9 \mathrm{a}$ & $70.2 \mathrm{a}$ & $66.6 \mathrm{a}$ \\
\hline & $\mathrm{N}_{180}$ & $48.8 \mathrm{a}$ & $51.4 \mathrm{~b}$ & $58.8 \mathrm{~b}$ \\
\hline & $\mathrm{N}_{240}$ & $47.3 \mathrm{a}$ & $37.6 \mathrm{c}$ & $58.2 b$ \\
\hline & $\mathrm{N}_{360}$ & $31.9 b$ & $23.6 \mathrm{~d}$ & $54.7 \mathrm{~b}$ \\
\hline \multicolumn{5}{|l|}{2019} \\
\hline \multirow[t]{5}{*}{ LC808 } & $\mathrm{N}_{0}$ & - & - & $62.8 \mathrm{a}$ \\
\hline & $\mathrm{N}_{120}$ & $48.6 a$ & 59.1a & $63.3 \mathrm{a}$ \\
\hline & $\mathrm{N}_{180}$ & $48.7 \mathrm{a}$ & $45.2 b$ & $57.7 \mathrm{~b}$ \\
\hline & $\mathrm{N}_{240}$ & $41.4 \mathrm{a}$ & $37.0 \mathrm{c}$ & $58.8 b$ \\
\hline & $\mathrm{N}_{360}$ & $33.9 b$ & $24.1 \mathrm{~d}$ & $52.6 \mathrm{~b}$ \\
\hline
\end{tabular}


Table 2. Cont.

\begin{tabular}{|c|c|c|c|c|}
\hline Cultivar & N Level & N Recovery Efficiency (\%) & N PFP (kg kg $\left.{ }^{-1}\right)$ & N Harvest Index (\%) \\
\hline \multirow[t]{5}{*}{ ZD958 } & $\mathrm{N}_{0}$ & - & - & $64.2 \mathrm{a}$ \\
\hline & $\mathrm{N}_{120}$ & $54.2 \mathrm{a}$ & $76.7 \mathrm{a}$ & $62.0 \mathrm{ab}$ \\
\hline & $\mathrm{N}_{180}$ & $51.9 \mathrm{a}$ & $53.8 b$ & $63.9 \mathrm{a}$ \\
\hline & $\mathrm{N}_{240}$ & $46.1 \mathrm{ab}$ & $39.6 c$ & $57.6 b$ \\
\hline & $\mathrm{N}_{360}$ & $33.6 \mathrm{~b}$ & $25.4 \mathrm{~d}$ & $60.3 \mathrm{ab}$ \\
\hline \multirow[t]{5}{*}{ DH685 } & $\mathrm{N}_{0}$ & - & - & $61.0 \mathrm{a}$ \\
\hline & $\mathrm{N}_{120}$ & $55.5 \mathrm{a}$ & $67.8 \mathrm{a}$ & $60.8 \mathrm{a}$ \\
\hline & $\mathrm{N}_{180}$ & $45.6 \mathrm{ab}$ & $49.9 b$ & $54.8 \mathrm{ab}$ \\
\hline & $\mathrm{N}_{240}$ & $38.0 \mathrm{ab}$ & $38.9 c$ & $56.3 \mathrm{ab}$ \\
\hline & $\mathrm{N}_{360}$ & $28.3 b$ & $26.2 d$ & $51.3 b$ \\
\hline \multicolumn{5}{|c|}{ ANOVA } \\
\hline \multicolumn{2}{|c|}{$\mathrm{N}$ rate $(\mathrm{N})$} & $14.01 * *$ & $546.17 * *$ & 0.47 \\
\hline \multicolumn{2}{|c|}{ Cultivar (C) } & 2.54 & $46.42^{* *}$ & $14.71^{* *}$ \\
\hline \multicolumn{2}{|c|}{ Year $(Y)$} & $14.48^{* *}$ & $43.24^{* *}$ & $18.25^{* *}$ \\
\hline \multicolumn{2}{|c|}{$\mathrm{N} \times \mathrm{C}$} & 0.34 & $2.99 *$ & $2.58 *$ \\
\hline \multicolumn{2}{|c|}{$\mathrm{N} \times \mathrm{Y}$} & 1.67 & 0.19 & $2.78^{*}$ \\
\hline \multicolumn{2}{|c|}{$\mathrm{C} \times \mathrm{Y}$} & $6.05^{* *}$ & 1.36 & 2.75 \\
\hline \multicolumn{2}{|c|}{$\mathrm{N} \times \mathrm{C} \times \mathrm{Y}$} & 0.49 & 1.49 & 1.17 \\
\hline
\end{tabular}

Additional letters denote significant differences $(p<0.05)$ between the different $\mathrm{N}$ levels of the same maize cultivar in the same year. Values are mean $\pm \mathrm{SD}(\mathrm{n}=3) .{ }^{*}$ and ${ }^{* *}$ indicate the variance with significance at the 0.05 , and 0.01 level, respectively.

\section{Discussion}

\subsection{Stay-Green Improves Crop Yields}

Since the twentieth century, crop yields and stay-green scores have steadily increased, and have had a positive correlation [25]. By the 1970s, stay-green was the most important phenotype for breeding selection, particularly for maize [6]. Defects in chloroplast destruction or senescence-promoting mechanisms can cause leaves to retain their green colour during senescence, a phenomenon called "stay-green" [26]. The stay-green trait was verified to delay leaf senescence, but more importantly, it maintained leaf photosynthesis following the flowering period and increased grain yields [27]. Stay-green crops were classified into four types based on the differences of genes in leaf senescence and expression time [28]: type A, initiation of the entire senescence syndrome may be delayed; type $B$, the syndrome may begin on time but proceed at a decelerated rate; type $C$ and type $\mathrm{D}$ were non-functional and had no value in production. Currently, the production of stay-green maize is primarily type $B$.

Regardless of type A or B, the delay in leaf senescence must be assured during the flowering to maturity period. Leaf senescence was primarily manifested as the leaf color changing from green to yellow until the whole leaf withered, where the internal mechanism was the reduction in chlorophyll content. As the SPAD value is a rapid and accurate method for representing chlorophyll [29,30], here, the classification of the stay-green scored in this study was based on the decrease in SPAD after flowering. Compared with the silking stage, the SPAD of LC808 at maturity was decreased by $82.1 \%$, which was defined as a non-stay-green cultivar. The SPAD of ZD958 at maturity was decreased by $39.5 \%$ and defined as a stay-green cultivar, whereas the SPAD of LC 808 at maturity was decreased by $22.7 \%$ and defined as an over-stay-green cultivar (Figure 3).

Plant cell membrane plays a role in regulating and controlling the exchange of substances inside and outside the cell, and its selective permeability is one of its most important functions. When the plant leaves are senescent or injured by stress, the cell membrane is damaged to varying degrees, the membrane permeability increases, the selective permeability is lost and the intracellular electrolyte exosmosis. The damage degree of membrane structure is related to the intensity of stress, the duration of stress, the resistance of crop varieties and other factors. Therefore, the determination of plasma membrane permeability can often be used as one of the physiological indexes of leaf activity [31-34]. 
In the present study, from the R1 to R6 stage, the mean relative EC increased by $170.0 \%$ in senescent LC808 maize, by $67.9 \%$ in the moderate-stay-green cultivar ZD958, and by $53.4 \%$ in the over-stay-green DH685 cultivar (Figure 5). This suggested that the degree of senescence for the stay-green cultivar was higher than that of the senescent type prior to the silking stage, whereas the rate of cell membrane damage of the senescent type was significantly higher than that of the stay-green type.

The rapid rise of relative EC exacerbated the decomposition of $\mathrm{Chl} a$; however, $\mathrm{Chl} b \operatorname{did}$ not decrease much from silking to maturity (Figure 4). The concentration of chl $a$ was higher than chl $b$ at any point of time throughout the vase-life [35]. Compared with Chl $b, \mathrm{Chl} a$ also absorbed and transferred light energy, and a small portion of Chl $a$ could convert light into electrical energy and produce chemical energy for dark reactions [36]. Research on rice also found that the Chl $a$ degraded more quickly than did Chl $b$ during aging [37]. However, whether of Chl $a$ was significantly reduced required further study.

The retention of $\mathrm{N}$ in leaves maintained a long-term photosynthetic capacity [13]; however, it was observed that the NHI of ZD958 (moderate-stay-green cultivar) was higher than the other two cultivars (Table 1). This study found that a large quantity of $\mathrm{N}$ in the stem was transferred to the grains to compensate for $\mathrm{N}$ retention in the leaves of cultivar ZD958 (Figure 7). However, the NHI of DH685 (over-stay-green cultivar) was lowest between the three cultivars, where the insufficient efficiency of $\mathrm{N}$ transfer in leaves might have been the critical factor.

\subsection{Effects of N Application on the Duration of Greenness for the Different Types of Stay-Green Maize}

The chlorophyll content of leaves can be significantly increased through the application of $\mathrm{N}$, which facilitates the use of light energy by leaves, while improving the conversion of light energy to chemical energy [38,39]. Taylor et al. (2010) found that the sufficient application of $\mathrm{N}$ fertilizer can inhibit chlorophyll degradation, maintain cell viability, and prolong leaf greenness in plants. However, the effects of $\mathrm{N}$ fertilizer on delaying senescence and increasing the chlorophyll content of different stay-green types of maize were not clear [40].

At maturity, the leaves of the senescent cultivar LC808 at different N levels were underwent chlorosis. Leaf chlorosis of the moderate-stay-green cultivar ZD958 was observed only under insufficient $\mathrm{N}$ levels, the leaves maintained greenness under all treatments (Figure 1), and changes in the SPAD and chlorophyll content well reflected the changes in leaf color (Figures 3 and 4). Additionally, the trend of relative EC was opposite to the chlorophyll content (Figure 5), which indicated that the N supply efficiently prolonged senescence for the stay-green and over-stay-green cultivars.

It is worth noting that the addition of $\mathrm{N}$ fertilizer had a negligible impact on senescent cultivars, which limited their high-yield potential. In our study, the theoretical maximum yield of LC808 was $7730.5 \mathrm{~kg} \mathrm{hm}^{-2}$, which was less than that of ZD958 $\left(8949.2 \mathrm{~kg} \mathrm{hm}^{-2}\right)$, and DH685 $\left(8775.6 \mathrm{~kg} \mathrm{hm}^{-2}\right)$, indicating it was difficult to a obtain high yield for the senescent cultivar (Figure 6).

\subsection{Optimal N Rate for the Different Types of Stay-Green Maize}

Insufficient or excessive $\mathrm{N}$ supplies can cause disorganized canopy structures that result in the degraded photosynthetic performance of crop populations, which can further reduce yields [41]. Our results demonstrated that leaf stay-green can improve maize yields; however, over-stay-green might reduce grain yields (Figure 2). As the plant N nutrient status was associated with the stay-green trait, dedicated $\mathrm{N}$ fertilizer management strategies should be specified for various types of stay-green maize.

In the present study, the regression equation results revealed that the optimal $\mathrm{N}$ application rate $\left(\mathrm{N}_{\text {opt }}\right)$ for LC808 $=228.1 \mathrm{~kg} \mathrm{hm}^{-2}, \mathrm{~N}_{\text {opt }}\left(\right.$ ZD958) $=180.0 \mathrm{~kg} \mathrm{hm}^{-2}$, and $\mathrm{N}_{\text {opt }}(\mathrm{DH} 685)=203.8 \mathrm{~kg} \mathrm{hm}^{-2}$ (Figure 6). Higher $\mathrm{N}$ absorption and $\mathrm{N}$ transfer efficiencies might be the main factors behind why stay-green cultivars do not require much fertilizer (Table 1). The highest attainable yield of over-stay-green cultivar was close to stay-green cultivar; however, the much higher levels of $\mathrm{N}$ retained in the straw could not transfer into grains, which resulted in higher $\mathrm{N}$ demands for the over-stay-green cultivar [12,42]. 
The extensive use of $\mathrm{N}$ fertilizers and the decline of $\mathrm{N}$ utilization efficiencies have caused widespread concern $[43,44]$. Big data has revealed that the maize N-PFP in China was only $25-37 \mathrm{~kg} \mathrm{~kg}^{-1}$; however, average global levels $\left(44-72 \mathrm{~kg} \mathrm{~kg}^{-1}\right)$ may be achieved though the improvement of $\mathrm{N}$ management strategies [45]. Cui et al. (2009) reported that the interaction between genotypes and nitrogen significantly influence grain yield and NUE in maize [46]. In the present study, the NRE and $\mathrm{N}-\mathrm{PFP}$ was decreased with higher $\mathrm{N}$ application rates, and there were extremely significant differences between $\mathrm{N}$ levels or cultivars (Table 1). When the highest yields were achieved, the N-PFP of LC808 was $\sim 37.5 \%$, the N-PFP of ZD958 was $\sim 53.2 \%$, and the N-PFP of DH685 was $\sim 49.4 \%$ (Figure 6; Table 2). China is the world's largest producer and consumer of $\mathrm{N}$ fertilizers, which is projected to account for more than half of the global consumption by 2050 [47]. Thus, the selection of stay-green crops is an important strategy for China toward reducing its use of $\mathrm{N}$ fertilizers, while increasing their efficiencies.

Furthermore, in contrast to the senescent cultivar, stay-green maize contained more $\mathrm{N}$ in its straw [48]. Since most farmers in China return full straw to their fields, $\mathrm{N}$ fertilizer inputs should be appropriately reduced for the next crop season, in conjunction with the planting of stay-green (including over-stay-green) crops.

\section{Conclusions}

Moderate-stay-green ZD958 cultivar yields were slightly higher than the over-stay-green type DH685 cultivar, and greater than the senescent LC808 cultivar. The $\mathrm{N}$ fertilizer supply significantly prolonged leaf greenness and delayed senescence for ZD958 and DH685; however, this effect was not obvious for LC808. To obtain the highest yields, the optimal $\mathrm{N}$ fertilizer rate for LC0808 was $228.1 \mathrm{~kg} \mathrm{hm}^{-2}, 180.0 \mathrm{~kg} \mathrm{hm}^{-2}$ for ZD958 and $203.8 \mathrm{~kg} \mathrm{hm}^{-2}$ for DH685. The $\mathrm{N}$ remobilization efficiency from stems was higher in the moderate-stay-green cultivar ZD958 over LC808, while less leaf N was transferred than in LC808. The residual N in straw at harvest was much higher in ZD958 and DH685; therefore, if farmers return all straw to their fields, $\mathrm{N}$ fertilizer inputs should be adjusted (reduced) accordingly for the following growing season.

Author Contributions: Conceptualization, Y.Y., Y.W. (Yang Wang), Y.H. (Yufang Huang); field experiment arrangements, W.F., S.Z., B.Z., Y.W. (Yin Wang), Y.H. (Yujie Hu); plant investigation and sample measurements, W.F., S.Z., B.Z., Y.W. (Yin Wang), Y.H. (Yujie Hu) and Y.H. (Yufang Huang); writing-original draft preparation, W.F., Y.W. (Yang Wang); writing—review and editing, Y.Z., and Y.Y.; funding acquisition, Y.Z., and Y.Y. All authors have read and agreed to the published version of the manuscript.

Funding: This work was financially supported by the National Key Research and Development Program of China (No. 2018YFD0200601, No. 2017YFD0200100) and the Innovation and Entrepreneurship Training Program for College Students in Henan Province (No. 201910466070).

Acknowledgments: We thank Ning Ren, Songhua Yue, Wenqing Guo for their help during the experiment.

Conflicts of Interest: The authors declare no conflict of interest.

\section{References}

1. Yang, Q.; Peter, B.K.; Xu, M.L. Quantitative disease resistance: Dissection and adoption in maize. Mol. Plant 2017, 10, 402-413. [CrossRef] [PubMed]

2. Food Agriculture Organization of the United Nations. Special Report FAO/WFP Crop and Food Security Assessment Mission to Mozambique; Food Agriculture Organization of the United Nations: Rome Italy, 2010.

3. Wang, N.; Wu, X.; Ku, L.; Chen, Y.; Wang, W. Evaluation of Three Protein-Extraction Methods for Proteome Analysis of Maize Leaf Midrib, a Compound Tissue Rich in Sclerenchyma Cells. Front. Plant Sci. 2016, 7, 1-856. [CrossRef]

4. Olopade, B.K.; Oranusi, S.U.; Nwinyi, O.C.; Lawal, I.A.; Gbashi, S.; Njobeh, P.B. Decontamination of T-2 Toxin in Maize by Modified Montmorillonite Clay. Toxins 2019, 11, 616. [CrossRef]

5. Zhu, X.; Shao, X.; Pei, Y.; Guo, X.; Li, J.; Song, X.; Zhao, M. Genetic Diversity and Genome-Wide Association Study of Major Ear Quantitative Traits Using High-Density SNPs in Maize. Front. Plant Sci. 2018, 9, 966. [CrossRef] [PubMed]

6. Thomas, H.; Ougham, H. The stay-green trait. J. Exp. Bot. 2014, 65, 3889-3900. [CrossRef] 
7. Wang, M.; Zhang, T.; Peng, H.; Luo, S.; Tan, J.; Jiang, K.; Heng, Y.; Zhang, X.; Guo, X.; Zheng, J.; et al. Rice Premature Leaf Senescence 2, Encoding a Glycosyltransferase (GT), Is Involved in Leaf Senescence. Front. Plant Sci. 2018, 9, 560. [CrossRef]

8. Willman, M.R.; Below, F.R.; Lambert, R.J.; Howey, A.E.; Mies, D.W. Plant traits related to productivity of maize. II. Development of multiple trait models1. Crop Sci. 1987, 27, 1122-1126. [CrossRef]

9. Gregersen, P.L.; Culetic, A.; Boschian, L.; Krupinska, K. Plant senescence and crop productivity. Plant Mol. Biol. 2013, 82, 603-622. [CrossRef]

10. Kamal, N.M.; Gorafi, Y.S.A.; Abdelrahman, M.; Abdellatef, E.; Tsujimoto, H. Stay-green trait: A prospective approach for yield potential, and drought and heat stress adaptation in globally important cereals. Int. J. Mol. Sci. 2019, 20, 5837. [CrossRef]

11. Hortensteiner, S. Stay-green regulates chlorophyll and chlorophyll-binding protein degradation during senescence. Trends Plant Sci. 2009, 14, 155-162. [CrossRef]

12. Chen, Y.; Xiao, C.; Wu, D.; Xia, T.; Chen, Q.; Chen, F.; Yuan, L.; Mi, G. Effects of nitrogen application rate on grain yield and grain nitrogen concentration in two maize hybrids with contrasting nitrogen remobilization efficiency. Eur. J. Agron. 2015, 62, 79-89. [CrossRef]

13. Mi, G.; Chen, F.; Zhang, F.; Cui, Z.; Liu, X. Nitrogen Uptake and Remobilization in Maize Hybrids Differing in Leaf Senescence. J. Plant Nutr. 2003, 26, 237-247. [CrossRef]

14. Kosgey, J.R.; Moot, D.J.; Fletcher, A.L.; Mckenzie, B.A. Dry matter accumulation and post-silking N economy of 'stay-green' maize (Zea mays L.) hybrids. Eur. J. Agron. 2013, 51, 43-52. [CrossRef]

15. Xin, W.; Zhang, L.N.; Zhang, W.Z.; Gao, J.P.; Zhao, Y.; Peng, C.C.; Zhao, C. An Integrated Analysis of the Rice Transcriptome and Metabolome Reveals Differential Regulation of Carbon and Nitrogen Metabolism in Response to Nitrogen Availability. Int. J. Mol. Sci. 2019, 20, 2349. [CrossRef]

16. Zhao, D.Y.; Tian, Q.Y.; Li, L.H.; Zhang, W.H. Nitric Oxide is Involved in Nitrate-induced Inhibition of Root Elongation in Zea mays. Ann. Bot. 2007, 100, 497-503. [CrossRef]

17. Jiang, C.Q.; Lu, D.J.; Zu, C.L.; Shen, J.; Wang, S.J.; Guo, Z.B.; Zhou, J.M.; Wang, H.Y. One-time root. zone N fertilization increases maize yield, NUE and reduces soil N losses in lime concretion black soil. Sci. Rep. 2018, 8, 1-10. [CrossRef]

18. Nazir, M.; Pandey, R.; Siddiqi, T.O.; Ibrahim, M.M.; Qureshi, M.I.; Abraham, G.; Vengavasi, K.; Ahmad, A. Nitrogen-deficiency stress induces protein expression differentially in low-N tolerant and low-N sensitive Maize genotypes. Front. Plant Sci. 2016, 7, 298. [CrossRef]

19. Gully, K.; Hander, T.; Boller, T.; Bartels, S. Perception of Arabidopsis AtPep peptides, but not bacterial elicitors, accelerates starvation-induced senescence. Front. Plant Sci. 2015, 6, 14. [CrossRef]

20. Yang, W.; Guo, Z.; Huang, C.; Wang, K.; Jiang, N.; Feng, H.; Chen, G.; Liu, Q.; Xiong, L. Genome-wide association study of rice (Oryza sativa L.) leaf traits with a high-throughput leaf scorer. J. Exp. Bot. 2015, 66, 5605-5615. [CrossRef]

21. Thornley, J.H.M. Acclimation of Photosynthesis to Light and Canopy Nitrogen Distribution: An Interpretation. Ann. Bot. 2004, 93, 473-475. [CrossRef]

22. Crafts-Brandner, S.J.; Below, F.E.; Wittenbach, V.A.; Harper, J.E.; Hageman, R.H. Differential Senescence of Maize Hybrids following Ear Removal. Plant Physiol. 1984, 74, 368-373. [CrossRef]

23. Christopher, J.T.; Christopher, M.J.; Borrell, A.K.; Fletcher, S.; Chenu, K. Stay-green traits to improve wheat adaptation in well-watered and water-limited environments. J. Exp. Bot. 2016, 67, 5159-5172. [CrossRef]

24. Lichtenthaler, H.K. Chlorophylls and carotenoids: Pigments of photosynthetic biomembranes. Method Enzymol. 1987, 148, 350-382.

25. Duvick, D.N.; Smith, J.S.C.; Cooper, M. Long-term selection in a commercial hybrid maize breeding program. Plant Breed. Rev. 2004, 24, 109-152.

26. Sakuraba, Y.; Lee, S.H.; Kim, Y.S.; Park, O.K.; Hörtensteiner, S.; Paek, N.C. Delayed degradation of chlorophylls and photosynthetic proteins in Arabidopsis autophagy mutants during stress-induced leaf yellowing. J. Exp. Bot. 2014, 65, 3915-3925. [CrossRef]

27. Lee, E.A.; Tollenaar, M. Physiological basis of successful breeding strategies for maize grain yield. Crop Sci. 2007, 47, S-202-S-205. [CrossRef] 
28. Thomas, H.; Smart, C.M. Crops that stay green. Ann. Appl. Biol. 1993, 123, 193-219. [CrossRef]

29. Erley, G.S.; Begum, N.; Worku, M.; Bänziger, M.; Horst, W.J. Leaf senescence induced by nitrogen deficiency as indicator of genotypic differences in nitrogen efficiency in tropical maize. J. Plant Nutr. Soil Sci. 2007, 170, 106-114. [CrossRef]

30. Robson, P.R.H.; Farrar, K.; Gay, A.P.; Jensen, E.F.; Clifton-Brown, J.C.; Donnison, L.S. Variation in canopy duration in the perennial biofuel crop Miscanthus reveals complex associations with yield. J. Exp. Bot. 2013, 64, 2373-2383. [CrossRef]

31. Li, Z.W.; Pan, X.F.; Guo, X.D.; Fan, K.; Lin, W.X. Physiological and Transcriptome Analyses of Early Leaf senescence for ospls1 mutant rice (Oryza sativa L.) during the grain-filling stage. Int. J. Mol. Sci. 2019, 20, 1098. [CrossRef]

32. Wang, X.; Xu, Y.; Li, J.; Ren, Y.; Wang, Z.; Xin, Z.; Lin, T. Identification of Two Novel Wheat Drought Tolerance-Related Proteins by Comparative Proteomic Analysis Combined with Virus-Induced Gene Silencing. Int. J. Mol. Sci. 2018, 19, 4020. [CrossRef] [PubMed]

33. Xiang, S.Y.; Ma, X.Z.; Liao, S.Y.; Shi, H.; Liu, C.Y.; Shen, Y.; Lv, X.; Yuan, M.T.; Fan, G.J.; Huang, J.; et al. Cellulose nanocrystal surface cationization: A new fungicide with high activity against phycomycetes capsic. Molecules 2019, 24, 2467. [CrossRef] [PubMed]

34. Liu, T.; Liu, Z.Q.; Li, Z.; Peng, Y.; Zhang, X.Q.; Ma, X.; Huang, K.K.; Liu, W.; Nie, G.; He, L.W. Regulation of heat shock factor pathways by $\gamma$-aminobutyric acid (GABA) associated with thermotolerance of creeping bentgrass. Int. J. Mol. Sci. 2019, 20, 4713. [CrossRef] [PubMed]

35. Elhindi, K.M. Evaluation of several holding solutions for prolonging vase-life and keeping quality of cut sweet pea flowers (Lathyrus odoratus L.). Saudi. J. Biol. Sci. 2012, 19, 195-202. [CrossRef]

36. Pinheiro, H.A.; Silva, J.V.; Endres, L.; Ferreira, V.M.; Camara, C.A.; Cabral, F.F.; Oliveiar, J.F.; Carvalho, L.W.T.; Santos, J.M.; Filho, B.G.S. Leaf gas exchange, chloroplastic pigments and dry matter accumulation in castor bean (Ricinus communis L.) seedlings subjected to salt stress conditions. Ind. Crop Prod. 2008, 27, 385-392. [CrossRef]

37. Biswas, A.K.; Choudhuri, M.A. Mechanism of monocarpic senescence in rice. Plant Physiol. 1980, 65, 340-345. [CrossRef]

38. Sivasankar, A.; Lakkineni, K.C.; Jain, V.; Abrol, Y.P. Differential response of two wheat genotypes to nitrogen supply. I. Ontogenic changes in laminae growth and photosynthesis. J. Agron. Crop Sci. 1998, 181, $21-27$. [CrossRef]

39. Vos, J.; Putten, P.E.; Birch, C.J. Effect of nitrogen supply on leaf appearance, leaf growth, leaf nitrogen economy and photosynthetic capacity in maize (Zea mays L.). Field Crop. Res. 2005, 93, 64-73. [CrossRef]

40. Taylor, L.; Nunes-Nesi, A.; Parsley, K.; Leiss, A.; Leach, G.; Coates, S.; Wingler, A.; Fernie, A.R.; Hibberd, J.M. Cytosolic pyruvate, orthophosphate dikinase functions in nitrogen remobilization during leaf senescence and limits individual seed growth and nitrogen content. Plant J. 2010, 62, 641-652. [CrossRef]

41. Pommel, B.; Gallais, A.; Coque, M.; Quilleré, I.; Hirel, B.; Prioul, J.K.; Andrieu, B.; Floriot, M. Carbon and nitrogen allocation and grain filling in three maize hybrids differing in leaf senescence. Eur. J. Agron. 2006, 24, 203-211. [CrossRef]

42. Chen, Y.; Xiao, C.; Wu, D.; Xia, T.; Chen, Q.; Chen, F.; Yuan, L.; Mi, G. Physiological and genetic mechanisms for nitrogen-use efficiency in maize. J. Crop Sci. Biotechnol. 2007, 10, 57-63.

43. Zhang, W.; Dou, Z.; He, P.; Ju, X.; Powlson, D.; Chadwick, D.; Norse, D.; Liu, Y.; Zhang, Y.; Wu, L.; et al. New technologies reduce greenhouse gas emissions from nitrogenous fertilizer in China. Proc. Natl. Acad. Sci. USA 2013, 110, 8375-8380. [CrossRef]

44. Liu, X.; Zhang, Y.; Han, W.; Tang, O.; Shen, J.; Cui, Z.; Vitousek, P.; Erisman, J.W.; Goulding, K.; Christie, P.; et al. Enhanced nitrogen deposition over China. Nature 2013, 494, 459-462. [CrossRef]

45. Cui, Z.; Zhang, F.; Mi, G.; Chen, F.; Li, F.; Chen, X.; Li, J.; Shi, L. Interaction between genotypic difference and nitrogen management strategy in determining nitrogen use efficiency of summer maize. Plant Soil 2009, 317, 267-276. [CrossRef]

46. Cui, Z.; Wang, G.; Yue, S.; Wu, L.; Zhang, W.; Zhang, F.; Chen, X. Closing the N-Use efficiency gap to achieve food and environmental security. Environ. Sci. Technol. 2014, 48, 5780-5787. [CrossRef] 
47. Good, A.G.; Beatty, P.H. Fertilizing nature: A tragedy of excess in the commons. PLoS Biol. 2011, 9, e1001124. [CrossRef]

48. Matile, P.; Hortensteiner, S.; Thomas, H. Chlorophyll Degradation. Annu. Rev. Plant Biol. 2006, 50, 67-95. [CrossRef]

(c) (C) 2020 by the authors. Licensee MDPI, Basel, Switzerland. This article is an open access article distributed under the terms and conditions of the Creative Commons Attribution (CC BY) license (http://creativecommons.org/licenses/by/4.0/). 